\title{
NEW SAFETY STANDARDS FOR COASTAL FLOOD DEFENCES IN THE NETHERLANDS
}

\begin{abstract}
Sebastiaan N. Jonkman'1, Ruben Jongejan², Bob Maaskant ${ }^{3}$, Han Vrijling ${ }^{4}$
The Dutch government is in the process of revising its flood safety policy. The current safety standards for flood defences in the Netherlands are largely based on the outcomes of cost-benefit analyses. Loss of life has not been considered separately in the choice for current standards. This article presents the results of a research project that evaluated the potential roles of two risk metrics, individual and societal risk, to support decision-making about new flood safety standards. These risk metrics are already used in the Dutch major hazards policy for the evaluation of risks to the public. Individual risk concerns the annual probability of death of a person. Societal risk concerns the probability of an event with many fatalities. Technical aspects of the use of individual and societal risk metrics in flood risk assessments as well as policy implications are discussed. Preliminary estimates of nationwide levels of societal risk are presented. Societal risk levels appear relatively high in the South Western part of the country where densely populated dike rings are threatened by a combination of river and coastal floods. Options for the application of the individual and societal risk in the new flood safety policy are presented and discussed.
\end{abstract}

Keywords: flood risk, loss of life, societal risk, safety standards

\section{INTRODUCTION}

Flood protection is of paramount importance to the low-lying Netherlands. The Dutch government is currently in the process of updating its flood risk management policy. EU Directive 2007/60/EC, the report of the Second Dutch Delta Committee (2008), and the recently published Dutch national water plan (Min VenW, 2008) all stress the need for evaluating flood probabilities and consequences in an integrated manner in a risk-based policy. In the year 2011 new flood safety standards will be defined, based on risk assessment. Current flood safety standards are largely based on the outcomes of costbenefit analyses that was carried out in the 1950's and 1960's. In addition, the Dutch government has indicated that it will explicitly and separately consider potential loss of life when deciding on the stringency of new flood safety standards (Min VenW, 2008). This paper discussed how loss of life can be taken into account in the derivation of the new safety standards. This remainder of this article is organized as follows. Section 2 provides background information on the individual risk and societal risk metrics used within the Dutch major hazards policy. The second part provides insight in methods for the quantification of individual and societal risks in the domain of flood safety and presents the results of nationwide estimates of societal risk (section 3). The final part (section 4) then discusses institutional consequences of alternative uses of individual and societal risk criteria within a flood safety policy. Concluding remarks for the whole study are discussed in the final section. During the preparation of the manuscript a longer version of the paper was accepted to the journal Risk Analysis (Jonkman et al., 2010) and that publication will give further background to interested readers.

\section{RISK METRICS USED WITHIN THE DUTCH MAJORD HAZARDS POLICY}

The Dutch major hazards policy deals with the risks to those living in the vicinity of major industrial hazards such as chemical plants and LPG-fuelling stations. The development of the Dutch major hazards policy was strongly incident driven, as were European efforts aimed at the prevention of major industrial accidents (Ale, 2005). After a number of severe industrial accidents, including the Bhopal accident in 1984 which killed an estimated 3000 people and severely injured over 200.000, a European directive was drafted concerning the prevention of major accidents: the 1982 Seveso Directive. This was later replaced by the Seveso II Directive. It covers a wide range of topics, ranging from plant safety requirements to inspection and land-use planning provisions. Because member states have had considerable freedom in implementing the directive, various types of major hazards policies can be found throughout the European Union. These can be grouped into two broad categories: effectbased approaches (e.g. Germany, France before the Toulouse accident) and risk-based approaches (e.g. UK, France after the Toulouse accident). While effect-based approaches use reference scenarios for evaluating risk acceptability, risk-based approaches consider a wide range of accident scenarios together with their probabilities. Under the latter approach, accident probabilities are an integral and

\footnotetext{
${ }^{1}$ Section of Hydraulic Engineering, Delft University, fac. Citg, Stevingweg 1, 2628 CN, Delft, the Netherlands \& Royal Haskoning, Coastal and Rivers Division

2 Jongejan Risk Management Consulting, Delft, the Netherlands \& Delft University, Section of hydraulic engineering

${ }_{4}^{3}$ HKV Concultants, Lelystad, the Netherlands

${ }^{4}$ Section of Hydraulic Engineering, Delft University
} 
explicit part of decisions on the acceptability of risks. The Dutch major hazards policy has remained firmly risk-based ever since its foundations were laid by the annex Premises for Risk Management in 1999.

The cornerstones of the Dutch major hazards policy are (i) quantitative risk analysis, (ii) individual and societal risk as risk-determining parameters and (iii) quantitative acceptability criteria for evaluating levels of individual and societal risk (Bottelberghs, 2000). Individual risk is defined as the probability of death of an average, unprotected person that is constantly present at a given location.

Individual risk criteria are reference levels for evaluating individual risks. The individual risk criteria were given a legal status in 2004 by the External Safety Decree. These limits to individual risk prevent disproportional individual exposures. Permits for property developments or plant modifications are denied if vulnerable objects would then be located within the $10^{-6}$ contour (Fig. 1).

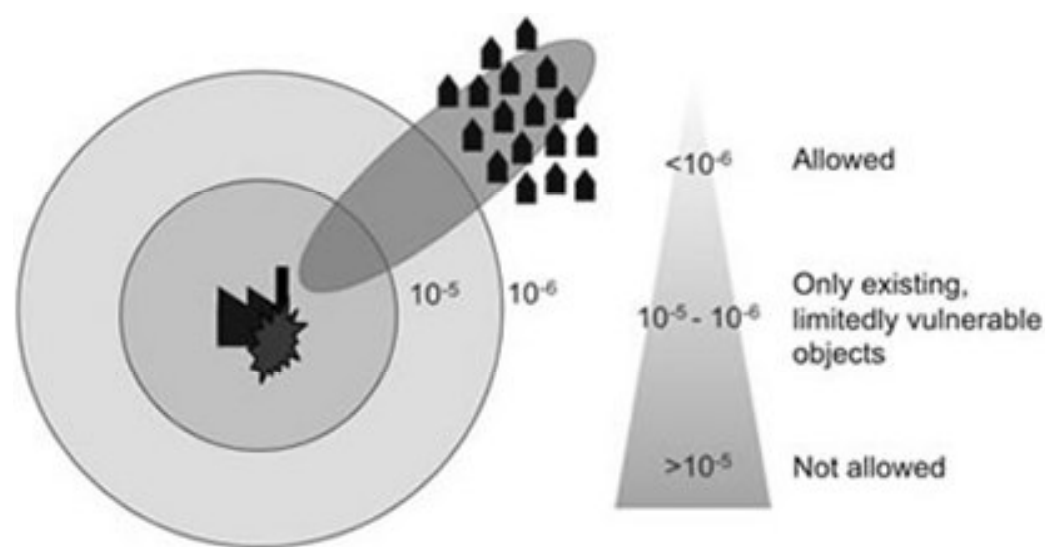

Figure 1: Individual risk contours around a hazardous establishment and the area affected by an individual accident scenario.

An individual risk criterion alone cannot prevent the too frequent occurrence of multi-fatality accidents. As shown in Figure 1, the area affected by an accident can differ considerably from the area that is defined by an iso-(individual)risk contour. When individual exposures are low, there could still be a chance that a single accident kills a large number of people. While a vast number of small accidents can go by largely unnoticed, multi-fatality accidents can shock a nation. Psychometric studies have indeed shown that "dread", or catastrophic potential, is an important factor in explaining risk perceptions (Slovic, 1987). To prevent the too frequent occurrence of large-scale accidents, societal risk criteria were implemented in the Netherlands. Societal risk refers to the probability of an accident with multiple fatalities. In general, it is graphically represented by an FN-curve that shows the exceedance probabilities of the potential numbers of fatalities $(\mathrm{P}(\mathrm{N} \geq \mathrm{n})$ ) on double log scale (Fig. 2).

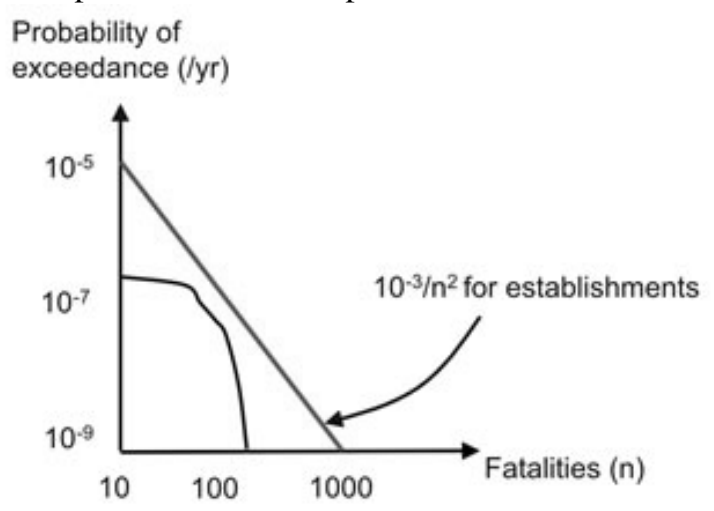

Figure 2: The Dutch societal risk criterion for hazardous establishments and a fictitious FN-curve. 
The Dutch societal risk criterion of $10^{-3} / \mathrm{n}^{2}$ per installation per year was initially developed for LPG-fuelling stations. It was later applied to all Seveso establishments. Similar societal risk criteria thus apply to hazardous establishments of different character and size despite considerable differences between the marginal costs of risk reduction in different cases (see (Jongejan, 2008) for further discussion).

Because the outcomes of quantitative risk analyses for low-probability industrial accidents are subjected to considerable uncertainty, the position of risk contours varies of orders of magnitude, depending on engineering judgment and model used (Ale et al., 2001). Since the outcomes of quantitative risk analysis (QRA) play an important role in the Dutch major hazards policy, such variability is troublesome for licensing purposes (land-use permits and operating permits). It was therefore decided to prescribe the use of a single risk model with little scope for interpretation on the part of risk analysts (Uijt de Haag et al., 2008). This, however, limits the opportunities for tailor-made risk analyses based on site-specific information.

\section{NATIONAL LEVELS OF SOCIETAL RISK}

\section{Background: Flood risk assessment and risk metrics}

Methods for the analysis of flood risk generally include three main steps: (1) determination of the probability of flooding; (2) simulation of flood characteristics; and (3) assessment of the consequences (e.g. (Apel et al., 2008). The implementation of these steps in flood risk assessment studies in the Netherlands has been described in detail in (Van Manen and Brinkuis, 2005; MinVenW, 2005). Such methods for flood risk generally include the following steps (1) determination of the probability of flooding; (2) simulation of flood characteristics; and (3) assessment of the consequences ${ }^{(9)}$. Based on the results of the risk analysis different risk metrics can be calculated, such as the expected number of fatalities or the expected economic damage. The risks to life for flooding can also be quantified with the metrics that are also used in the major hazards policy. Following the definition that is used in the Dutch major hazards policy (see section 2), IR is determined for a person that is constantly present at a given location. The calculated IR is a property of a certain location and it can be used for risk-based land use planning. An alternative definition of individual risk could be used that refers to the probability of death of a person at a location including the effectiveness of evacuation. In addition the societal risk level for flooding can quantified based on probability and consequence estimates for a set of flood scenarios. The results can be shown by means of an FN-curve.

\section{Nationwide estimates of Societal Risk: Approach}

The results of detailed flood risk analyses are expected after the year 2011, but policymakers wanted to gain insight in the severity of fatality risks well before that date in the context of policy development. A study was therefore commissioned to estimate nationwide levels of societal risks. ${ }^{(10)} \mathrm{A}$ simplified procedure was therefore designed to estimate societal risks from floods on the basis of available data. It rests on the following assumptions:

- In case of flooding, at least one person is killed. The probability of flood therefore equals the probability of at least one fatality

- The conditional distribution of the number of fatalities is exponential. This implies that larger numbers of fatalities are increasingly less likely in case of flood.

The first assumption seems relatively uncontroversial as failures of primary flood defences are lowprobability, high-impact events. The second assumption is based on the observation that the three available FN-curves that were derived from detailed risk estimates (Jonkman et al., 2009) match this assumption relatively well. Comparison of the approximation with the calculated FN-curves for three areas showed that the exponential curve matches the outputs of detailed risk estimates well. Although the second assumption is obviously coarse, an assumption regarding the shape of FN-curves is unavoidable if we are to estimate $\mathrm{FN}$-curves for all dike rings on the basis of currently available data.

The FN-curve with the exponential distribution is given by:

$$
P(N \geq n)=P_{f} \cdot e^{-\frac{(n-\xi)}{\sigma}} \text { for } \mathrm{n} \geq \xi
$$


where: $P(N \geq n)=$ probability of $n$ or more fatalities [per year]; $P_{f}=$ probability of flood [per year]; $\xi$ $=$ threshold value that determines the starting point of the exponential distribution; $\sigma=$ standard deviation of the number of fatalities given flood [-].

The threshold value $\xi$ equals the minimum number of fatalities in case of flood. It has been assumed that at least one person is killed in case of flood. Since the number of fatalities is an integer, both $\xi=0$ and $\xi=1$ would match this assumption. Here, a value of $\xi=0$ was chosen. In that case, the expected number of fatalities given a flood equals the standard deviation, i.e. $\mu=\sigma$. Estimating FNcurves now requires only two figures per dike ring: an estimate of the probability of flood, and an estimate of the average number of fatalities in a flood. The procedures for these estimates are presented in the next section.

\section{Input information: flood probabilities and fatalities}

For estimates of the flood probabilities, information was used from a large ongoing government project, Water Safety in the $21^{\text {st }}$ Century. In that study, flood probabilities were determined for all dike rings in the Netherlands. It was assumed that the flood defences comply to the current safety standards (based on probabilities of exceedance) and that this situation corresponds to the situation in the year 2015. The resulting flooding probabilities per dike ring are shown in figure 3. The probabilities are somewhat lower than the existing safety standards as it was assumed that the actual critical overtopping discharge that the dikes are able to withstand $(5 \mathrm{l} / \mathrm{s} / \mathrm{m})$ is somewhat higher than the current design criterion for overtopping discharge $(1 \mathrm{l} / \mathrm{s} / \mathrm{m})$.

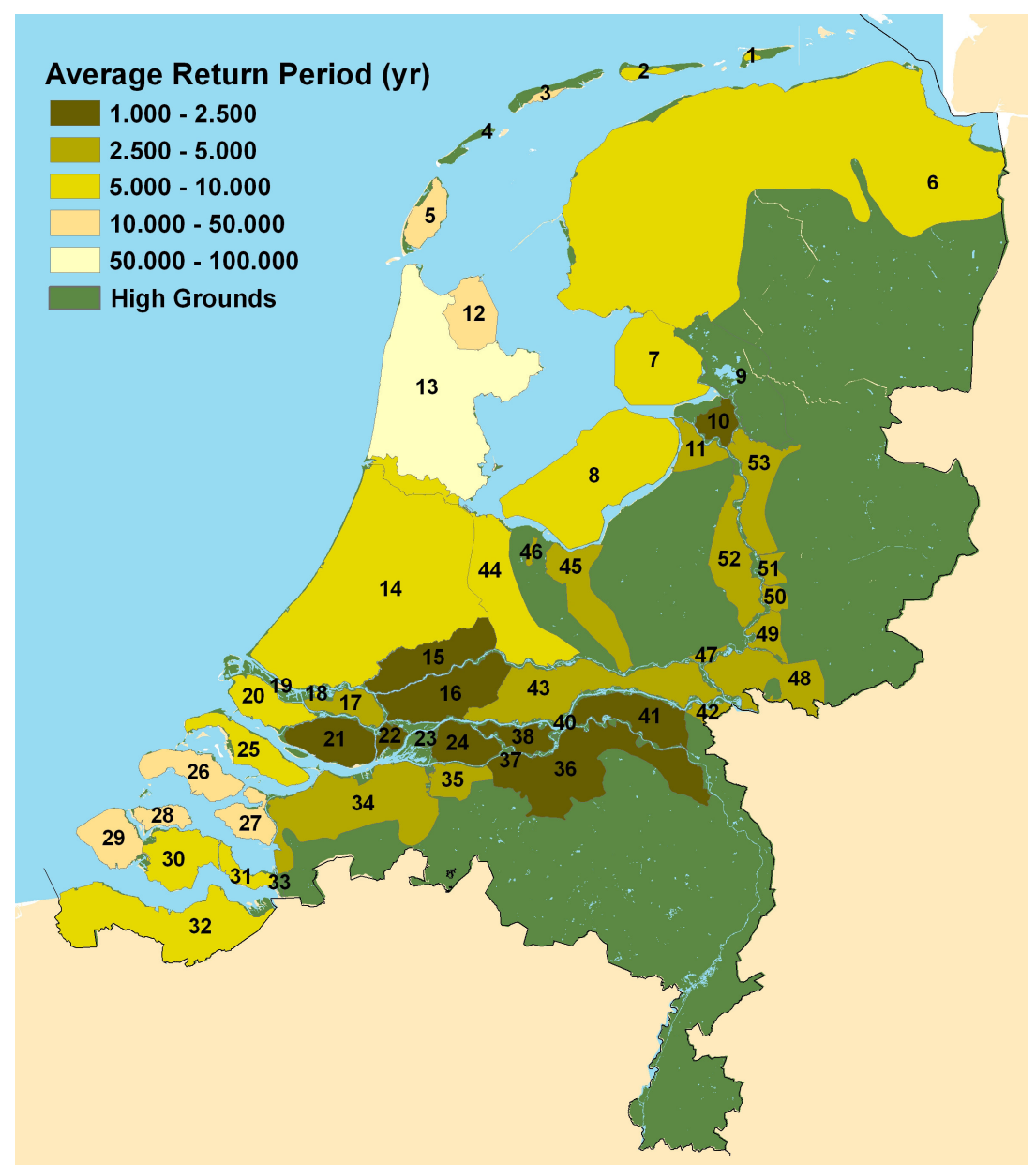

Figure 3: Estimated flooding probabilities (the numbers in the areas refer to the numbers that are included to indicate dike rings in the Flood Defence Act).

The number of fatalities can be calculated according to: 


$$
N=N_{P A R} F_{E X P}\left(1-F_{E}\right) F_{D}
$$

where: $N=$ number of fatalities [-]; $N_{P A R}=$ number of people in the dike ring [-]; $F_{E X P}=$ fraction of the total population in the flooded area [-]; $F_{E}=$ fraction of people evacuated [-]; $F_{D}=$ mortality i.e. the percentage of people killed by the flood [-].

In order to estimate the expected number of fatalities given flooding, average values for these parameters were estimated on the basis of available data and expert judgment. The number of people in the dike ring $\left(\mathrm{N}_{\mathrm{PAR}}\right)$ approximately equals the number of inhabitants, This quantity has been obtained from national population datasets. Due to variations in elevation and limitations in inflowing water a flood event will generally not flood the whole dike ring area and thus not affect the entire population. The fraction of the population that is in the flooded parts of the dike ring $\left(\mathrm{F}_{\mathrm{EXP}}\right)$ is estimated based on available information on flood scenarios, elevation and population (Klijn et al., 2007). The fraction of the people evacuated has been determined from a nationwide study on evacuation fractions per dike ring (Goudappel Coffen, 2008) in which traffic models have been applied to estimate the time required for evacuation. For the estimation on the mortality $\left(F_{D}\right)$ flood events were grouped into three broad categories. These are defined by the severity of the flood, water depths and/or flow velocities, and to what extent the flood comes unexpected, with little or no warning. The three categories are:

- Dike ring with severe flooding (large water depths, high flow velocities, unexpected): mortality equals $1 \%$, so $\mathrm{F}_{\mathrm{D}}=0.01$; This is the estimate used for dike rings along the coast.

- Dike rings with some warning time but still extensive flooding: mortality is assumed $0.7 \%$; dike rings that are both influenced by sea and river.

- Dike rings with long warning time and to some extent expected flood: mortality $0.5 \%$; dike rings along rivers.

These estimates on event mortality have been based on available detailed risk studies for individual areas (Jonkman et al., 2009). Combining the above variables according to equation (2) yields estimates for the expected number of fatalities given flooding. The results for all dike rings are shown in figure 4.

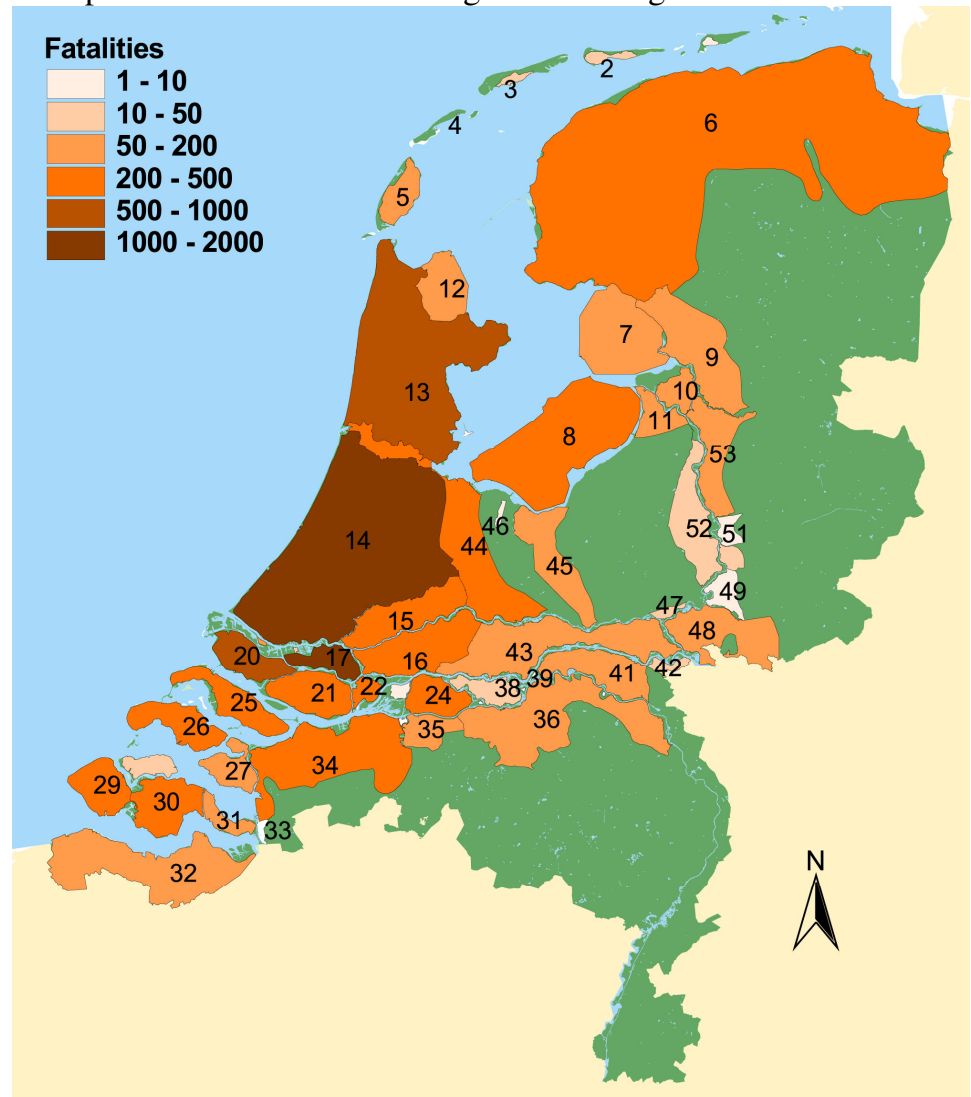

Figure 4: Expected number of fatalities given flooding by dike ring. 


\section{Results of nationwide estimates of societal risk}

Based on the method and input data presented in the previous sections FN-curves were estimated for the dike rings in the Netherlands. The results are shown in figure 5. Each curve represents the FNcurve for one dike ring and the number refers to the dike ring numbers included in the Flood Defence Act (see figure 3 or 4 ).

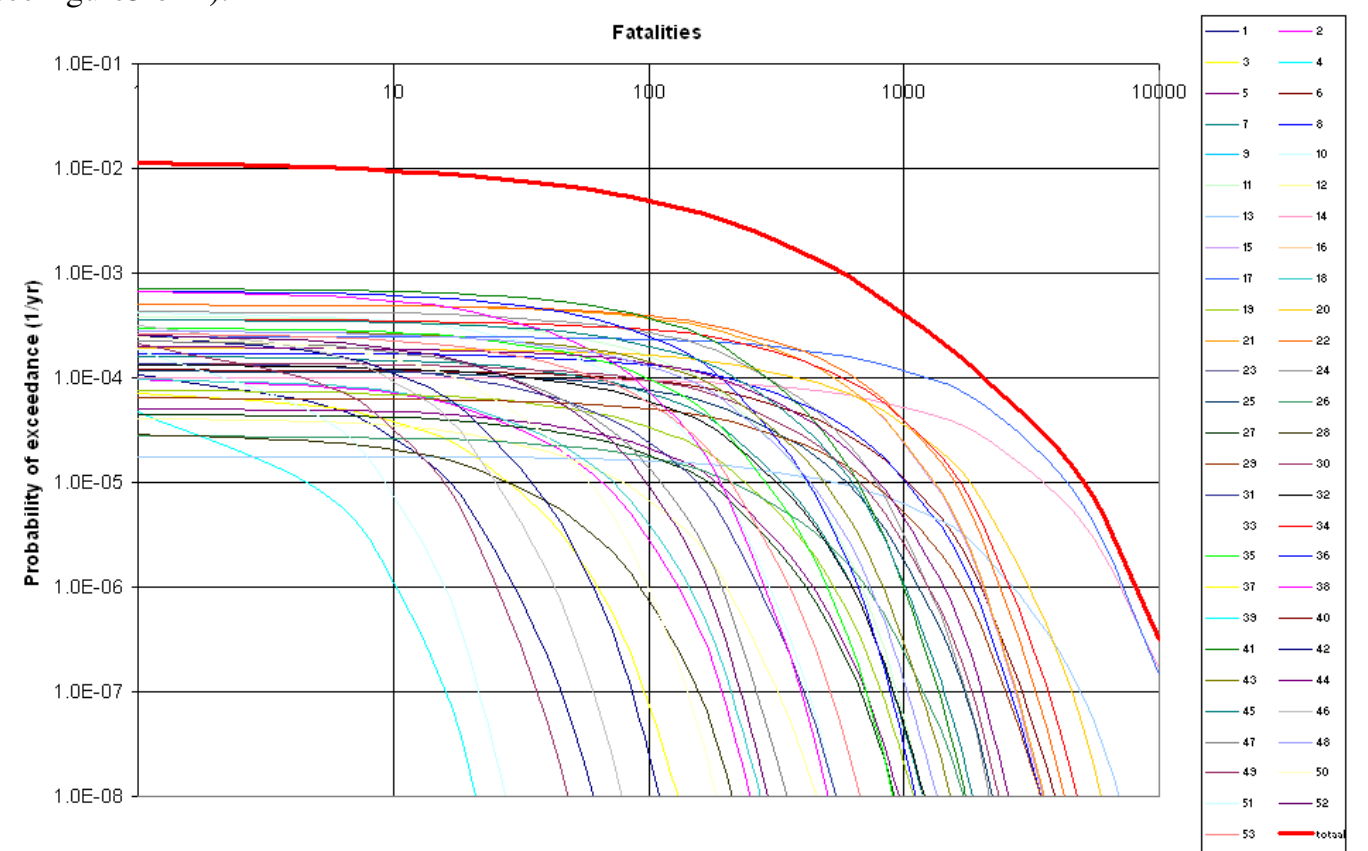

Figure 5: FN-curves for individual dike rings and the total FN-curve for flooding for the Netherlands.

The national level of societal risk is shown as a bold line and has been estimated by vertically adding the FN-curves of the individual dike rings. This implies (as a first approximation) that floods in different dike rings are mutually exclusive events. This assumption is further discussed below.

As part of the investigation, the societal risk levels of different dike rings were analysed and compared. For decision-making purposes it is relevant to provide insight into the areas where societal risks are highest and the areas that contribute strongly to the national level of societal risk. Two dimensions, i.e. exceedance probabilities and consequences, determine the level of societal risk of a dike ring. For reasons of presentation and communication the level of societal risk for each dike ring was characterized by means of a single value: the point where a tangent line with the calculated FN-line crosses the $y$-axis of the FN-curve (see figure 6). The tangent line has the following general formulation:

$$
P(N \geq n)=C / n^{\alpha}
$$

where: $P(N \geq n)=$ probability of exceedance of $n$ fatalities [per year]; $C=$ constant that determines the point where the tangent line crosses the y-axis of the FN-curve [per year]; $\alpha=$ steepness of the tangent line;

It should be noted that this formulation is exactly the same as the typical formulation of an FNlimit line. The tangent line that is found for a certain area thus equals the limit line for which the situation would just be acceptable. The value of constant $C$ thus represents the vertical position of the tangent line. A quadratic steepness of the tangent line $(\alpha=2)$ was chosen because the same slope is used within the Dutch major hazards policy. This is a risk averse criterion and it is expected that this value will be used in further discussions about flood safety. 


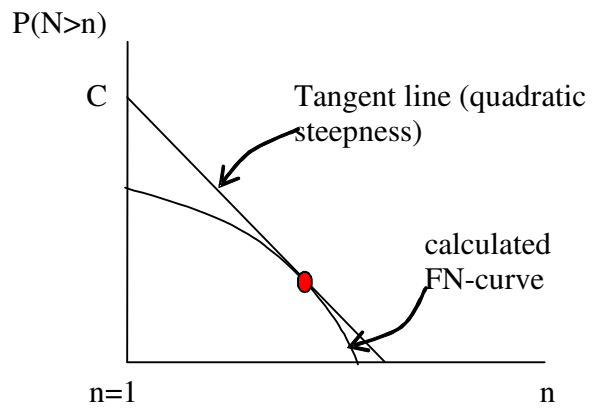

Figure 6: Determination of the tangent line and constant $\mathrm{C}$ for a calculated FN-curve.

$C$-values were determined for the Dutch dike rings, see figure 7 for the results. For most of the dike rings, the events with fatalities in the range between 100 en 10,000 fatalities determined the $C$-values. Table I provides more detailed information for the eight dike rings with the highest $C$-values.

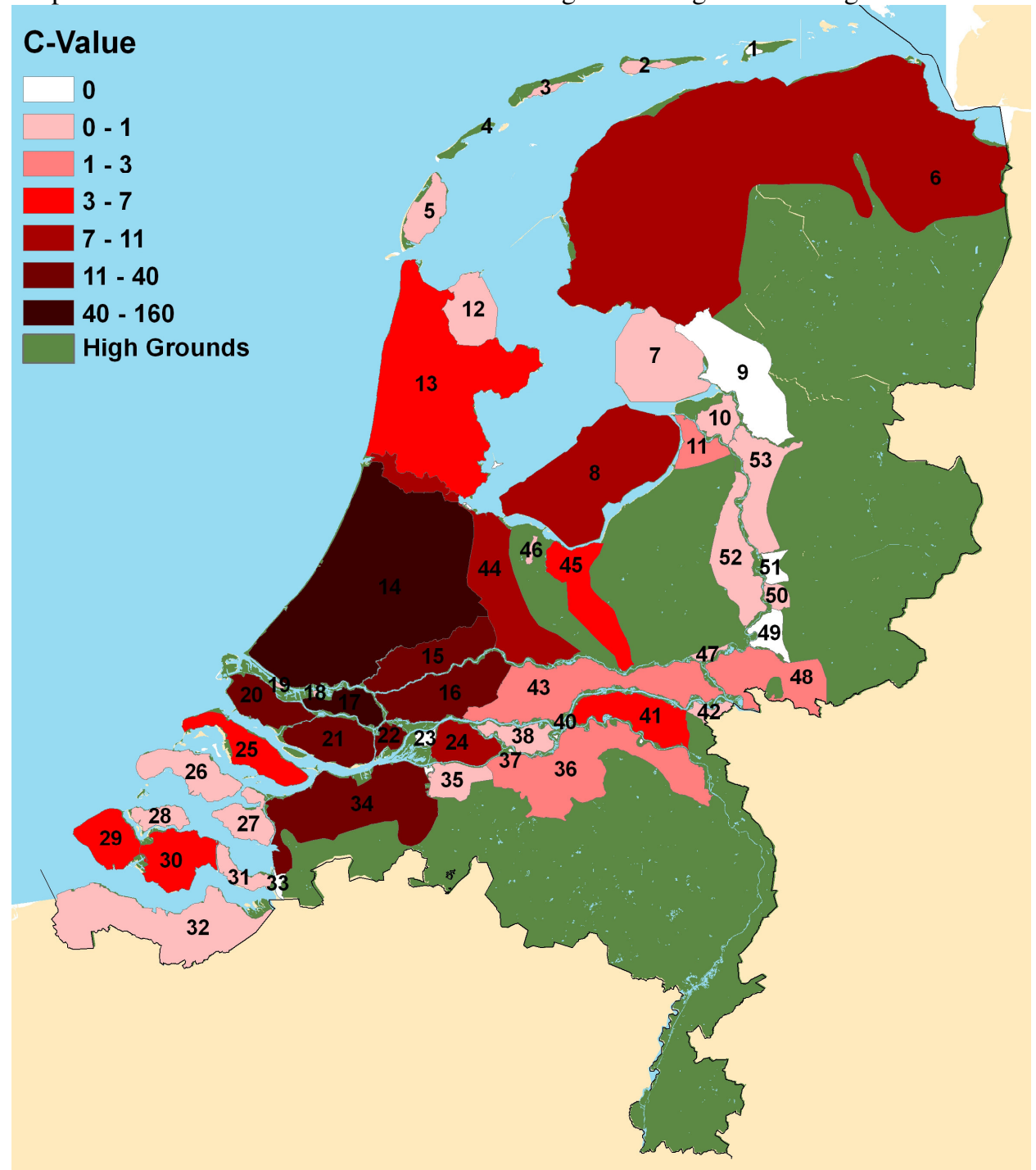

Figure 7: $C$-values for dike rings in the Netherlands (indicating the relative level of societal risk). 


\begin{tabular}{|c|c|c|c|c|}
\hline nr. & Name & $\begin{array}{l}\text { flooding } \\
\text { probability }\end{array}$ & $\begin{array}{c}\text { expected } \\
\text { number of } \\
\text { fatalities }\end{array}$ & C-value \\
\hline 17 & IJsselmonde & $2.5 \times 10^{-4}$ & 1341 & 150 \\
\hline 14 & Zuid-Holland & $1.0 \times 10^{-4}$ & 1566 & 103 \\
\hline 22 & Eiland van Dordrecht & $5.0 \times 10^{-4}$ & 393 & 39 \\
\hline 34 & West-Brabant & $3.57 \times 10^{-4}$ & 452 & 39 \\
\hline 20 & Voorne-Putten & $1.92 \times 10^{-4}$ & 600 & 36 \\
\hline 16 & Alblasserwaard \& Vijfheerenlanden & $5.0 \times 10^{-4}$ & 332 & 28 \\
\hline 21 & Hoeksche Waard & $5.0 \times 10^{-4}$ & 332 & 28 \\
\hline 15 & Lopiker en Krimpenerwaard & $5.0 \times 10^{-4}$ & 328 & 27 \\
\hline
\end{tabular}

From figure 7, it can be seen that dike rings in the southwestern part of the Netherlands have relatively high levels of societal risk. This is due to the fact that these dike rings are densely populated, and that there is limited time for evacuation as the coastal floods that threaten these areas cannot be predicted well in advance. As part of the investigation, the relationship between the C-values and the probability and consequence estimates was analysed.

This shows that there is a weak relationship between the C-value and the flooding probability estimates. A much stronger relationship exists between the $\mathrm{C}$-value and the consequence estimates. This is not surprising as a) the differences between the probability estimates for most of the dike rings are relatively small ; b) the consequences have a quadratic influence due to the choice for a quadratic tangent line. Further investigation did not reveal a strong, persistent relationship between the C-value and the underlying factors that influence the consequences of floods, such as the number of inhabitants, the size of the area at risk, or the population density. The estimates of the number of fatalities depend on dike ring specific combinations of these factors.

A sensitivity analysis was carried out using a different steepness of the tangent line $(\alpha=1)$. This steepness corresponds to an FN-criterion that places equal weight on exceedance probabilities and numbers of fatalities. This type of FN-criterion is often indicated as risk-neutral. With $\alpha=1$, the group of the eight dike rings with the highest $\mathrm{C}$-values remains the same, although the ranking within this group becomes somewhat different.

\section{Societal risk and cumulation}

In the determination of the national level of societal risk, the possibility that floods occur simultaneously in different dike rings should be taken into account. Experience from historical floods, both in the Netherlands and abroad, shows that multiple dike rings are likely to flood simultaneously under extreme conditions. For example, in the big flood of 1953, approximately 140 breaches occurred at approximately 10 of the (current) dike ring areas. In the insurance industry, the effect of correlations between individual loss experiences on the distribution of overall losses is called cumulation. It is relevant for the estimation and evaluation of societal risks. Due to the simultaneous flooding of multiple dike rings, the consequences of a single flood event will increase. The effects of cumulation have not been discussed in detail in this paper. Preliminary societal risk estimates that include cumulation are presented in (Jonkman et al., 2010). It was found that cumulation, the simultaneous flooding of multiple dike rings during a single flood event, could have significant impacts on the national level of societal risk. 


\section{POTENTIAL USES OF INDIVIDUAL AND SOCIETAL RISK CRITERIA IN THE DUTCH FLOOD SAFETY POLICY}

\section{Evaluating individual and societal risks}

As also discussed in previous sections, loss of life will play a role in the design of new safety standards for flood defences in the Netherlands. Loss of life can be evaluated from two distinct perspectives (Vrijling et al., 1995; 1998; Stallen et al., 1996): 1) The individual perspective: the safety of a particular individual. 2) The societal perspective: the probabilities of large numbers of fatalities.

A limit to individual risk can be used to guarantee a minimal safety level to every individual living behind a primary flood defence. The introduction of such a basic safety level has also been proposed by the Second Delta Committee (2008). The proposed individual risk limit equaled $10^{-6}$ per year (including the effectiveness of evacuation) for the provision of flood safety to those living behind primary flood defences. The proposed value is similar to the individual risk limit used in the Dutch major hazards policy (with the exception that evacuation is not considered in this field). Further research is needed to see whether such a stringent safety standard would also be feasible for the Dutch flood safety policy, given the measures that would have to be taken.

FN-curves show the probability distribution of the number of fatalities and can be used for the evaluation of fatality risks from a societal perspective. To facilitate the evaluation of FN-curves, criterion lines could be defined: an FN-curve should, in principle, not exceed the criterion line. An FNcriterion is defined by three variables: (i) its base point (the exceedance probability of 1 fatality), (ii) its slope, and (iii) its probability and/or consequence cut-off. Figure 8 shows the different constraints that could make up an FN-criterion.

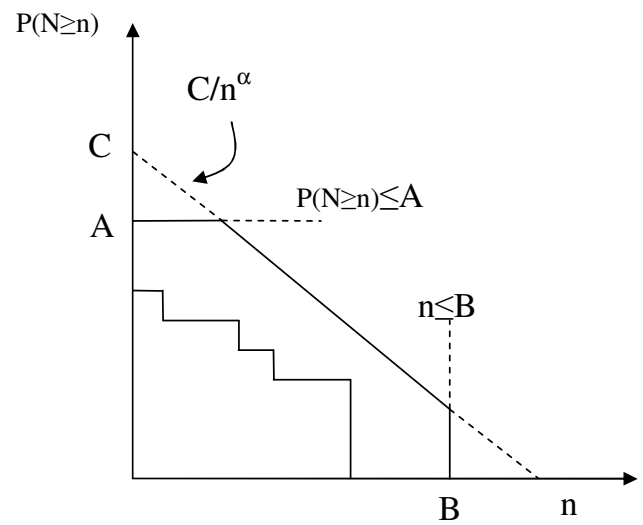

Figure 8: A fictitious FN-curve and different FN-criteria.

A theoretical link between expected utility theory and FN-criteria might be hard, if not impossible, to establish (Jongejan, 2008) and the use of FN limit-lines has been criticized on that ground (Evans and Verlander, 1997). Yet FN-criteria have proven themselves in the Dutch major hazards policy as practical tools for the evaluation of the probabilities of large-scale accidents. The FN-criteria used in the Dutch major hazards policy have a quadratic steepness, meaning that the exceedance probability of 10 times as many fatalities should be 100 times lower. This has been motivated by public aversion to large numbers of fatalities. A recent study on flood events found that individuals are more concerned about "low probability / high damage" flood events than reflected by the annual expected value of flood damages (Merz et al., 2009). It should however be noted that FN-curves with different slopes are used in different counties (Ball and Floyd, 1998).

The stringency of societal risk criteria could, amongst other, be based on cost-benefit considerations on risk-risk comparison across domains (Vrijling et al., 1998). Relative levels of societal risk within one domain could also be evaluated by comparing levels of societal risk in different objects (e.g. dike ring areas) as a basis for prioritization. 
Societal risk can be quantified and evaluated for areas of different sizes, for example for a city, a province, a dike ring, a hydrological subsystem, or an entire country. The boundaries of such areas could be aligned with institutional boundaries. Various government actors are responsible for influencing (mitigating or creating) flood risks, most notably the national government, provinces, municipalities, and water boards. Each of these entities has its own territorial boundaries. An alternative would be to align the boundaries of the areas for which societal risk is evaluated with those of the natural system, such as the boundaries of hydrological systems (e.g. Rhine, Meuse, coast) or dike rings (note that the boundary of a dike ring does not necessarily coincide with the territorial boundary of a water board). It is currently being proposed to evaluate societal risk at the dike ring level because: (i) current safety standards are also defined per dike ring and the future safety standards will likely have the same format (MinVenW, 2008); (ii) measures taken at a dike ring will mostly affect the risk within that ring, and (iii) current risk studies are mainly focusing on separate dike rings. An assessment of the risks at the national scale would provide insight in the threat at a national level. By combining information for the different spatial scales, those areas and subsystems could be identified that give the highest contribution to the overall national level of risk.

\section{The status given to individual and societal risk criteria}

Individual and societal risk could play a number of different roles in a flood safety policy, depending partly on the status that is given to the yardsticks for judging the acceptability (or tolerability) of individual and societal risks.

Under the least binding alternative, individual and societal risk are merely used for agenda-setting and/or policy evaluation purposes. Policymakers consider (past or potential changes in) levels of individual and societal risk when making policy choices. There is no formal rule stipulating a need for action when some predefined level of individual or societal risk is exceeded.

A second option would be to define criteria or reference values for evaluating individual and/or societal risks, but to allow exceedances when there are strong reasons for doing so. Decision rules that seem reasonable in some cases, might lead to grossly disproportionate outcomes in other. Allowing for flexibility can reduce the unintended social cost of rules and regulations, but it can dramatically increase transaction cost (the cost of decision making). In the Dutch major hazards policy, there is no legal limit to societal risk, only a reference value. Exceedances of this reference value (as well as increases in societal risk below the reference value) have to be properly motivated by competent authorities. The External Safety Decree lays down the basic elements that have to be considered by competent authorities, and jurisprudence has led to further refinement of the definition of a "properly motivated" decision.

Under the third and most stringent regime, the government lays down legal limits to individual and societal risks. These limits would then have a similar status as the exceedance probabilities that are currently laid down in the Flood Defence Act. When prevention would be the basis for the flood risk management policy the government could also define maximum flood probabilities, based on considerations related to individual and societal risks. For example, for each dike ring, the probability of flood would have to be reduced until the level of societal risk would be lower than the limit line (see also figure 8). Limits to individual and/or societal risk would effectively find their way into the legal limits to flood probabilities.

It should be noted that the Dutch central government is responsible for living up to the Water Act (previously: Flood Defence Act). In this respect, the functioning of the Water Act is rather different from e.g. the External Safety Decree (see section 2) that lays down the rules of the game that individuals, firms and local governments have to play by. If local governments fail to observe the rules laid down in the External Safety Decree, their decisions can be challenged in court. But in the domain of flood safety, the government plays the role of the provider of a public good. Flood safety standards effectively define the government's (public's) level of ambition when it comes to the provision of flood protection. If central government fails to meet the standards laid down in the Flood Defence Act out of budgetary considerations, the government cannot be successfully challenged in court. This is because budgetary decisions are legitimized through the workings of the political system, the same system that 
legitimized the Water Act. Experience has however shown that legally defined flood safety standards can be highly effective in setting government priorities, as they provide a clear basis for the evaluation of the safety of flood defences and make it virtually impossible for failures to meet predefined safety standards to go by unnoticed.

\section{Options for using individual and societal risk in the Dutch flood safety policy}

As outlined in the previous sections, individual and societal risk can play different roles in shaping and implementing a new flood safety policy in the Netherlands. Key policy choices concern:

- The status of individual and/or societal risk: agenda-setting/policy design, reference values, legal limits

- The stringency of individual and/or societal risk criteria: when risk criteria are implemented (as either reference values or legal limits), how stringent should they be?

- The strategy for reducing flood risks: reducing flood probabilities, reducing the consequences of floods, a combination of both

Based on the three strategies for reducing flood risks, three policy alternatives were defined (table II). According to current policy documents (MinVenW, 2008), the focus will rest on limiting the risks to life and the economy through prevention (the first strategy: the reduction of flood probabilities). In addition, the possibilities for reducing the consequences of floods will be investigated through land-use planning for existing vulnerable facilities and to guide the development of future land use.

The three strategies for reducing flood risks have different institutional implications. If, for instance, the decision were made to mitigate risks through a combination of flood prevention and safety zoning, rules would have to be laid down to ensure that local governments do not allow or develop spatial plans that lead to increases in potential damages (note that the interests of an individual local government and the central government need not be perfectly aligned).

Designing rules and regulations that steer the behaviour of local governments and property developers into a direction deemed desirable by central government would not just require answers to questions of a purely technical nature (e.g. how to ensure that the joint behaviour of individual entities does not lead to excessive societal risks?), but also to questions of a political and institutional nature (e.g. how to deal with conflicts of interest between local governments that wish to minimize restrictions on spatial plans and a central government that wishes to minimize investments in flood prevention?).

\begin{tabular}{|c|c|c|c|c|}
\hline $\begin{array}{l}\text { Strategy for } \\
\text { reducing flood risks, } \\
\text { by reducing: }\end{array}$ & $\begin{array}{l}\text { Characteristics and } \\
\text { implications }\end{array}$ & $\begin{array}{l}\text { Standard / policy } \\
\text { instruments }\end{array}$ & Measures & Parties involved \\
\hline 1) flood probabilities & $\begin{array}{l}\text { Consequences are given, } \\
\text { increase of consequences } \\
\text { compensated by smaller } \\
\text { flooding probability }\end{array}$ & $\begin{array}{l}\text { Prevention, flood } \\
\text { probability reduced } \\
\text { (determined from cost- } \\
\text { benefit analysis and } \\
\text { evaluation of fataility risks) }\end{array}$ & $\begin{array}{l}\text { Dike } \\
\text { strenghtening } \\
\text { Room for } \\
\text { Rivers }\end{array}$ & $\begin{array}{l}\text { Flood defence } \\
\text { management } \\
\text { authorities }\end{array}$ \\
\hline 2) consequences & $\begin{array}{l}\text { Flood probability is given } \\
\text { (e.g. based on CBA), } \\
\text { policy focuses on reducing } \\
\text { the consequences. } \\
\text { Thereby possible } \\
\text { limitations for spatial } \\
\text { planning and economic } \\
\text { growth. }\end{array}$ & $\begin{array}{l}\text { Steering development of } \\
\text { consequences, e.g. by } \\
\text { zoning } \\
\text { Growth of consequences } \\
\text { could limited by requiring } \\
\text { a so-called stand-still of } \\
\text { risks (i.e. no increase of } \\
\text { risks allowed) }\end{array}$ & $\begin{array}{l}\text { Spatial } \\
\text { planning, } \\
\text { zoning, flood- } \\
\text { proof } \\
\text { construction, } \\
\text { shelters and } \\
\text { mounds, } \\
\text { evacuation } \\
\end{array}$ & $\begin{array}{l}\text { Land use planning } \\
\text { \& Emergency } \\
\text { management } \\
\text { authorities }\end{array}$ \\
\hline $\begin{array}{l}\text { 3) probabilities and } \\
\text { consequences }\end{array}$ & $\begin{array}{l}\text { Case-by-case evaluation } \\
\text { of measures to reduce the } \\
\text { probability or } \\
\text { consequences, e.g. based } \\
\text { on effectiveness and side } \\
\text { effects. Can lead to } \\
\text { complex and therefore } \\
\text { time consuming and costly } \\
\text { decision-making } \\
\text { procedures.. }\end{array}$ & $\begin{array}{l}\text { Cost Benefit Analysis, } \\
\text { Evaluation of fatality risks }\end{array}$ & $\begin{array}{l}\text { Dike } \\
\text { strenghtening } \\
\text { Room for } \\
\text { Rivers } \\
\text { zoning, flood- } \\
\text { proof } \\
\text { construction, } \\
\text { shelters and } \\
\text { mounds, } \\
\text { evacuation }\end{array}$ & $\begin{array}{l}\text { Flood defence } \\
\text { management, } \\
\text { Land use planning } \\
\text { \& Emergency } \\
\text { management } \\
\text { authorities }\end{array}$ \\
\hline
\end{tabular}




\section{CONCLUDING REMARKS}

The Dutch government is currently in the process of updating its flood risk management policy. One of the novelties being considered concerns a role for fatality risks in evaluating flood risks. Fatality risks already play an important role in the Dutch major hazards policy. Individual risk limits are used there to provide a minimal safety level to those living in the vicinity of major industrial hazards; societal risk criteria are used to prevent the too frequent occurrence of large-scale accidents. This article reviewed the potential for using individual and societal risk for flood risk management. Techniques are available for quantifying these metrics when it comes to floods ${ }^{(9)}$ and it has been shown that individual and societal risk can be used for comparing the effectiveness of alternative risk mitigation strategies and for appraising flood risks.

Preliminary nationwide estimates of societal risks from floods in the Netherlands indicate that the levels of societal risk are expected to be relatively high in the southwestern part of the country where densely populated dike rings are threatened by both river and coastal floods. These areas therefore deserve specific attention when it comes to flood risk mitigation.

From a purely technical standpoint, little stands in the way of using individual and societal risk for the evaluation of flood risks. But evaluating risks and designing a flood safety policy are not purely technical exercises. Key policy choices concern the status of individual and/or societal risk criteria (or the decision not to formulate criteria), the stringency of such criteria, and the chosen strategy for mitigating flood risks.

Obviously, loss of life is only one of the vast number of consequences that together make up the personal and social impact of a large-scale flood. As loss of life is often considered to be one of the most important consequence types, a separate evaluation of fatality risks constitutes a significant improvement over an approach that focuses on the economics of flood safety alone. The presented approach could therefore also be relevant for other (European) countries, as most flood risk assessments focus on potential economic damage rather than loss of life.

It is emphasized that the results presented in this article are preliminary and based on a combination of available information from risk assessments and expert judgment. Further detailed risk studies are necessary to come to a more detailed and accurate understanding of the level of fatality risks from floods throughout the Netherlands. The outcomes of the FLORIS project are expected after the year 2011. These outcomes will include estimates of the spatial distribution of individual risks.

\section{ACKNOWLEDGMENTS}

The authors want to thank dr. Matthijs Kok (Delft University and HKV consultants) and Alex Roos (Rijkswaterstaat) for their contributions to this research.

\section{REFERENCES}

Ale BJM. Tolerable or Acceptable: A Comparison of Risk Regulation in the United Kingdom and in the Netherlands. Risk Analysis, 2005. 25(2): 231-241.

Ale BJM, Golbach GAM, Goos D, Ham K, Janssen LAM, Shield SR. Benchmark risk analysis models. Bilthoven, the Netherlands, RIVM report 610066015. 2001.

Apel H, Thieken AH, Merz B, Bloschl GA. Probabilistic modelling system for assessing flood risk. Natural Hazards, 2006; 38(1-2): 79-100.

Ball DJ, Floyd PJ. Societal risks. Report submitted to HSE. 1998.

Bottelberghs PH. Risk analysis and safety policy developments in the Netherlands. Journal of Hazardous Materials, 2000; 71: 117-123.

Delta Committee. Working together with water - Findings of the Deltacommissie 2008. Den Haag, Netherlands: Hollandia Printing, 2008.

Evans AW, Verlander NQ. What is wrong with criterion FN-lines for judging the tolerability of risk. Risk Analysis 1997; 17 (2): 157-168.

Goudappel Coffeng, Universiteit Twente. Veiligheid Nederland in Kaart-modellering en analyse van evacuatie. Delft, DWW007/Fok/0093. 28 April 2008. 
Jongejan RB. How safe is safe enough? The government's response to industrial and flood risks. Doctoral thesis. Delft University of Technology. Delft, The Netherlands. 2008.

Jonkman SN, Vrijling JK, Kok M. Flood risk assessment in the Netherlands: A case study for dike ring South Holland, Risk Analysis, 2008; 28 (5): 1357-1373.

Jonkman S.N., Jongejan R.B., Maaskant B. (2010) The use of individual and societal risk criteria within the Dutch flood safety policy - nationwide estimates of societal risk and policy applications. Risk Analysis, Accepted, in Press.

Klijn F, Baan P, de Bruijn K, Kwadijk J, van Buuren R. Overstromingsrisico's in Nederland in een veranderend klimaat. Delft, WL rapport Q4290.00. 2007.

Merz B, Elmer F, Thieken AH. Significance of "high probability / low damage" versus "low probability / high damage" flood events. Natural Hazards and Earth System Sciences, 2009; 9: 1033-1046.

MinVenW (Ministry of Transport Public Works and Water Management). Floris-study: full report. The Hague. DWW report 2005-081. 2005.

MinVenW (Ministry of Transport Public Works and Water Management). Ontwerp nationaal waterplan (in Dutch). Zaandam, Netherlands: Kwak \& van Daalen \& Ronday, 2008.

Slovic P. Perception of Risk. Science, 1987; 236: 280-285.

Stallen PJM, Geerts R, Vrijling JK. Three conceptions of quantified societal risk. Risk Analysis, 1996;16(5): 635-644.

Uijt de Haag PAM, Gooijer L, Frijns PJMG, Quantitative risk calculation for land use decisions: the validity and the need for unification, In: Kao T.M. Zio M. Ho V. (Eds.). Int. Conf. on Probabilistic Safety Assessment and Management. PSAM9 Hong Kong. (digital proceedings) 2008.

Van Manen SE, Brinkhuis M. Quantitative flood risk assessment for Polders. Reliability Engineering and System Safety, 2005; 90: 229-237.

Vrijling JK, van Hengel W, Houben RJ. Acceptable risk as a basis for design. Reliability Engineering and System Safety, 1998; 59: 141-150.

Vrijling JK, van Hengel W, Houben RJ. A framework for risk evaluation, Journal of hazardous materials, 1995; 43 (3): 245-261. 